\title{
DIÁRIO DE NARCISO E NEUROLINGUÍSTICA DISCURSIVA: 30 ANOS DEPOIS
}

\author{
MARIA IRMA HADLER COUDRY ${ }^{1}$ \\ UNICAMP/CNPQ
}

A meus alunos ${ }^{2}$ Especialmente a Maria Beatriz Gobby Bandini (In Memoriam) ${ }^{3}$

\begin{abstract}
RESUMO: Este ensaio apresenta um apanhado dos principais movimentos do projeto Neurolinguística Discursiva: afasia e infância, apoiado pelo CNPq, com foco na relação entre escrita na afasia e escrita infantil, por meio de dados que revelam um curso comum entre a criança e o afásico, em tempos diversos da vida. A criança entrando no sistema de escrita e o afásico tendo perdido relações que sustentam esse sistema. Destaca-se, também, a articulação teórica - novos e velhos autores -, realizada para dar continuidade à despatologização de crianças normais e à correlação entre afasia e infância. Ressalta-se, ainda, o investimento nas parcerias previstas no Projeto, com Fernanda Freire e Sonia Sellin Bordin. Com Freire demos continuidade aos temas da avaliação discursiva/prática discursiva, ao banco de dados de neurolinguística $(\mathrm{BDN})$, bem como à visibilidade das cenas enunciativas que este último confere aos dados, condição fundamental para a análise e a escrita de caso. A questão do ritmo da fala e da escrita foi focalizada nos dados de afásicos e iniciantes de escrita. Com Bordin, continuamos analisando dados que ampliam e refinam a relação entre afasia e infância, investimos na análise da relação com as famílias e escolas, destacando como incluir crianças que estão barradas no aprendizado da leitura/escrita. Também refinamos a descrição dos dois ambientes discursivos que são a fonte de dados do BDN: o CCA e o CCazinho. A metodologia, tema presente nas diversas produções da área, é retomada neste texto.
\end{abstract}

Palavras-chave: Neurolinguística Discursiva; linguagem; afasia e infância; fala, leitura e escrita.

${ }^{1}$ Professora Titular do Departamento de Linguística, Instituto de Estudos da Linguagem/ Unicamp. Contato: coudry@iel.unicamp.br 2012).

${ }^{2} \mathrm{O}$ ofício de ensinar é como a arte de representar. O palco é a vida que se transforma (COUDRY,

${ }^{3}$ Bia Bandini estava escrevendo sua tese de doutorado (orientada por mim), quando todos fomos surpreendidos com sua morte precoce. O trabalho tematizava a Doença de Alzheimer (DA) e ela acompanhava longitudinalmente o sujeito $\mathrm{BC}$ para configurar, junto com outros autores da ND, um estudo de caso, para depois compará-lo com estudos de casos de sujeitos com afasia desenvolvidos ao longo de 20 anos, até aquela época, desde minha tese de doutorado, em 1986. Tradicionalmente, a Neurologia e a Neuropsicologia descrevem na DA uma fase afásica, hipótese a que nos contrapomos. A hipótese que levantamos, considerando os dados de $\mathrm{BC}$ e sua análise linguístico-cognitiva, no que toca ao signo linguístico, é que tal estado progressivo afeta preferencialmente o significado, enquanto a afasia afetaria preferencialmente a face significante. 
ABSTRACT: This essay, which was initially a research report, addresses a collection of the main movements of Neurolinguistic Discursive Project: aphasia and childhood, a project which is supported by $\mathrm{CNPq}$, and which focuses on the relation between writing in aphasia and children's writing, through data that reveal a common course between the child and the aphasic in different moments of their lives. The children's first steps into the writing system and the aphasics who have lost mechanisms that underpin this system. The theoretical articulation - new and previous authors - is also highlighted to continue the dispatologization of normal children and the correlation between aphasia and childhood when it comes to reading, speaking and writing. Partnerships foreseen in the project gave results: with Freire, we proceeded on the topics discursive evaluation / discursive practice, the neurolinguistics database $(\mathrm{BDN})$, as well as the visibility of the enunciative scenes that it confers to the data, a fundamental condition for the analysis and the writing case. The matter of speech and writing rhythm was focused on the aphasics and writing beginners data analysis. With Bordin, we proceeded with the data analysis that broaden and refine the relationship between aphasia and childhood, we invest in the analysis of the relationship with families and schools, highlighting how to include children who are stuck in reading/writing processes. We also refine the description of the two discursive environments that are the data source of BDN: CCA and CCazinho. The methodology, an issue which is present in several of our articles, is taken up again in this one.

Keywords: Discursive Neurolinguístics, language; aphasia and childhood; speach, reading and writing.

\section{PRÓLOGO}

O projeto de estudar a linguagem em estados patológicos começa com um sonho, em 1972, no meio da graduação em Linguística: duas grandes montanhas, à semelhança de dois hemisférios cerebrais, sendo iluminadas por um sol radiante, representando a linguagem - que interpretei como a busca de uma relação entre linguagem e cérebro (HADLER, 1978), a primeira iluminando o segundo. E para uma linguista comprometida com a questão do sentido, com a Análise do Discurso, a Teoria da Enunciação, a Semântica Enunciativa e Argumentativa, o sujeito é peça fundamental por sua historicidade, singularidade e relação com o outro.

Do encontro com o Prof. Yvan Lebrun, em 1981, nascia o encontro com a Afasia e os sujeitos afásicos, (d)escritos ${ }^{4}$ no Diário de Narciso (COUDRY, [1986], 1988). Nascia um projeto: estudar Neurolinguística com Lebrun, na Universidade Livre $^{5}$ e no Hospital Bordet, em Bruxelas, no melhor sentido do tradicional. Como linguista, estudar o patológico (afasia) e relacioná-lo com o normal (aquisição), iluminada pelos processos dialógicos formulados por Lemos (1982) para analisar a fala da criança. O afásico repetia os mesmos processos, o que me fez debruçar em estudos longitudinais da afasia centrados em aspectos linguísticos. Avaliação e acompanhamento longitudinal. Análise de interlocuções com afásicos. Tive a sorte de Narciso ser meu primeiro sujeito afásico, aquele que inaugura os estudos discursivos.

${ }^{4} \mathrm{O}$ Método que a Neurolinguística de tradição discursiva (ND) tem de fazer ciência é a escrita de caso, como no Diário de Narciso, em que escrevo o caso de três sujeitos em um estudo longitudinal. Uma escrita que pode ser revista, como uma escrita da escrita, em que novas articulações teóricas e novos dados-achados confluem para uma reescrita. Lugar de dúvidas metódicas, busca de explicação para aquela produção, naquele contexto, busca de compreensão do caso. Lugar de análise de dados, interpretação teoricamente motivada: achar o dado-achado no processo usando a escrita para tecer o raciocínio intelectual em jogo é uma questão de Método para os estudos realizados pela ND.

${ }^{5}$ Lembrança feliz de Luc De Vreese e Norberto Rodrigues. 
Vários conceitos que alicerçam a Neurolinguística de tradição discursiva (ND) são mobilizados no Diário de Narciso, imersos no encontro entre afásico e não afásico, para investigar a relação afasia/linguagem, interpelada por uma concepção de linguagem como trabalho/atividade (FRANCHI, [1977] 2002), cujos protagonistas são sujeitos, incompletos por sua condição humana, que emanam do interdiscurso. Nessa relação com o afásico, reafirma-se a centralidade da interlocução/enunciação, a (inter)subjetividade, a ocupação de papéis discursivos na cena discursiva, por meio de práticas discursivas (MAINGUENEAU, 1981, [1987] 1989), que nos fazem sujeitos (OSAKABE, 1979). Processos de significação que caracterizam a linguagem, em suas várias dimensões/níveis de análise (BENVENISTE, [1969] 1995a), na afasia, possibilitam a comparação inevitável entre esse estado patológico e a linguagem infantil (FREUD, [1891] 2010; JAKOBSON, [1941] 1980).

Onde desembocou a ND nos últimos anos, e depois de mais de 30 anos? Na releitura dos clássicos (COUDRY, 2002 COUDRY, 2012): no estudo do balbucio, verbal e motor, que são esquecidos para dar lugar a uma organização em sistemas de gestos verbais e não verbais, quando a criança entra na linguagem e na cultura, ou seja, quando atravessa o rubicão rumo ao simbólico. Nesse ponto ela se aproxima do afásico que, por regressão funcional, tem apagados certos subsistemas e realçados outros antes esquecidos, o que o leva a retomar estruturas e processos vivenciados na infância.

A força vital de Canguilhem (1995), que se aproxima da força/função criadora de Franchi ([1977] 2002), é crucial para o sujeito se movimentar, refazer certos trajetos barrados por onde o sentido pode ser refeito ${ }^{6}$. É nesse processo que acontece o encontro entre sujeitos, no discurso, lugar em que ocorre a avaliação e o seguimento longitudinal, propostos no Diário de Narciso. A entrada na linguagem tem muita semelhança com a sua involução, momento em que subsistemas se desorganizam/desautomatizam e afetam os eixos que sustentam o funcionamento da linguagem, sucessividade/simultaneidade (JAKOBSON, [1941] 1980). É quando o afásico e a criança lançam mão de processos alternativos de significação que geralmente não coincidem com os oficiais, instituídos na língua, mas representam caminhos possíveis; representam a criatividade ${ }^{7}$ na aquisição e também na linguagem afetada pela afasia.

${ }^{6}$ A força vital possibilita a invenção de formas novas de responder às dificuldades que ocorrem ao longo da vida, o que tem um sentido semelhante ao papel da criatividade constitutiva do trabalho com a linguagem.

${ }^{7}$ Exemplo disso é a solução criativa de GM, cuja afasia afeta a leitura e a escrita, ao ler o título da notícia do Correio Popular de 21/03/2017 sobre a apreensão de balões pela polícia: Polícia prende ladrões - solução criativa, motivado pelo contexto de corrupção em que vivemos; leu uma coisa por outra, com parafasias que caíram bem. Outro sujeito, SL, com afasia verbal/motora, em novembro de 2003, queria dizer a palavra eclipse e não conseguia. A solução criativa que encontrou foi escrever a letra "E" junto de um clips (clipes) que retirou da agenda da interlocutora. 
Para expor o atual movimento da ND, que contempla a relação entre afasia e infância, sobretudo o estudo da escrita nesses dois momentos da vida, apresento as últimas reflexões acerca dessa relação ${ }^{8}$.

\section{APRESENTAÇÃO}

Este texto apresenta um apanhado do estado atual da teorização que desenvolvemos na Neurolinguística Discursiva (ND), destacando a relação entre afasia e infância e concentrando no investimento realizado em torno de dois pilares da pesquisa: a avaliação discursivamente orientada, incluindo o registro no Banco de Dados em Neurolinguística (BDN), e a patologização de processos normais de aquisição da escrita. O tema afasia e infância é central na pesquisa empreendida nos últimos 10 anos e os dados dessa relação atravessam nossos estudos, convocando novas e revisitando velhas ideias.

Tenho conduzido o estudo das afasias e da patologização da infância - que representam a dificuldade de viver (COUDRY, 2012) em dois tempos da vida (vida adulta e início da vida) - na direção de uma Neurolinguística Responsável (de responsabilidade ${ }^{9}$ ), implicada na experiência do sujeito com a linguagem e o mundo em que vive seu tempo presente. Implicada nas transformações do século XXI, relativas à sociedade, à família, e sua (re)estruturação, às relações que estabelecemos, às escolhas, essa formulação da ND é inspirada em Forbes (2012), que, por sua vez, tem como referência Freud e, especialmente, Lacan, em sua segunda clínica. Implicada na relação com o sujeito, mediada pela linguagem, em seus múltiplos acontecimentos, enfrentando o que caracteriza o discurso (seu caráter prévio, heterogêneo e incompleto), a ND recusa a idealização desse sujeito.

\section{AVALIAÇÃO DISCURSIVAMENTE ORIENTADA}

Conforme a teorização que assumimos na ND e o que nossos estudos têm apontado, os contextos de uso da linguagem (a ser avaliada e focalizada no seguimento longitudinal) dizem respeito ao uso variado da linguagem, em faces

8 Refiro-me, especialmente, a meu último Relatório da bolsa de produtividade (CNPq. 312522/2013-4) em que apresento os principais desdobramentos teórico-metodológicos em torno do Projeto Neurolinguística Discursiva: afasia e infância, no triênio 2014-2017, que compuseram uma nova proposta de continuidade ao estudo da relação afasia e infância - como um encontro inevitável -, recém-aprovada para o triênio 2017-2020.

${ }^{9}$ Penso que a Fonoaudiologia que se articula à ND, vinculada, portanto, à Linguística, exerce o papel de uma clínica responsável, experienciando as escolhas dentre as muitas que o mundo disposto em redes suscita para o sujeito na contemporaneidade (BIRMAN, 2012; FORBES; 2012; COUDRY, 2014b). E se preparando para essa empreitada. A parceria com o linguista pode ser muito interessante para ambos que podem atuar na criação de contradispositivos, tecnicamente orientados, que atuam na prática, para combater a patologização como uma espécie de defeito inevitável, que penetra na realidade por meio de dispositivos de saber e de poder (FOUCAULT, 1987; AGAMBEN, 2009) que assujeitam e fabricam sujeitos a seu gosto. Combater e propor outra coisa em seu lugar. Trabalho em várias mãos. 
e registros (RIBEIRO, 2001) e com interlocutores também diversos, por onde a linguagem se expõe e se pode conhecer as dificuldades do sujeito, atentando para sua história. Pode-se teorizar sobre elas, incorporando outros autores e conceitos e revisitando os já achados, tendo como referência, por exemplo, os níveis de análise linguística (BENVENISTE, [1969] 1995a) e sua inter-relação no funcionamento discursivo da linguagem. O que não fazemos é aplicar na avaliação discursos condicionados por tarefas metalinguísticas para diagnosticar/ classificar prevendo como será o seguimento longitudinal/terapêutico - como ocorre na perspectiva tradicional ${ }^{10}$ (quantitativa), essencialmente baseada em testes padronizados e a-históricos (COUDRY, [1986] 1988; 1995; 2008; 2013; FREIRE, 1999; NOVAES-PINTO, 1992, 1999; COUDRY e FREIRE, 2010; BORDIN, 2010; ANTONIO, 2011; MULLER, 2013; RIGHI-GOMES, 2014; SILVA, 2014).

É dessa atitude discursiva comprometida com a construção/interpretação do sentido frente aos fatos da linguagem que derivam os protocolos de avaliação, historicamente informados, denominados de versões protocolares ${ }^{11}$ (COUDRY, 2001; COUDRY e FREIRE, 2016), assentadas em práticas discursivas (como se verá no próximo item) que funcionam nas diversas atividades linguageiras que travamos com as pessoas com quem nos relacionamos com maior ou menor proximidade, com os textos que lemos/escrevemos, enfim com nossa experiência de linguagem vivida no mundo. Nos estudos longitudinais que desenvolvemos, apresentamos tais versões que produzem, na interlocução travada entre afásico(s) e não afásico(s), e entre afásicos; criança(s) e adulto(s), e entre crianças, os dados que analisamos. A relação entre língua, linguagem e sociedade orienta as propostas desenvolvidas nas versões protocolares de que são compostos a avaliação e o seguimento longitudinal (COUDRY, 1995). Ou seja, os dados são produzidos na interação entre os sujeitos e as cenas enunciativas (MAINGUENEAU, [1987] 1989; COUDRY, 2012) que daí derivam, especialmente as cenografias (MAINGUENEAU, 2005), e compõem uma determinada versão protocolar, cujo vínculo com outras é sua condição histórica de discursos anteriores/memória discursiva. O discurso, como considera Maingueneau (2005), não acontece em um espaço já construído e autônomo, mas na enunciação/interlocução que o constitui e que sustenta a cenografia que o legitima. A noção de cenografia de Maingueneau ([1998] 2004, 2005) reafirma a centralidade da enunciação e do interdiscurso, o que se afina com os propósitos da ND (COUDRY, 2012) de produzir versões protocolares - historicamente datadas - que se estabelecem na interlocução e não tarefas eternizadas e que se repetem para quaisquer sujeitos.

${ }^{10}$ A ND tem definido como tradicional abordagens que estudam, avaliam e lidam com a linguagem no contexto patológico e escolar, desconsiderando o saber técnico produzido pela Linguística e produzindo equívocos como efeito desse desconhecimento.

${ }^{11}$ No item 5, Notas sobre a Metodologia, descrevo um pouco mais a relação entre o o quê e como fazemos nossa prática de avaliação e seguimento longitudinal. 


\subsection{Avaliação como prática discursiva}

De acordo com Maingueneau (1989), o conceito de prática discursiva envolve a reversibilidade essencial entre as duas faces do discurso, a textual (verbal) e a social, e em cujo trânsito se dá a relação da língua com a cultura. Isso implica falar do que se fala, do que se faz, do que acontece, pode ou não acontecer, do que se ouve, do que se escreve, do que se lê, do que não tem importância e do importante, etc. Assim, a avaliação leva em conta, por constituir-se em meio às várias práticas discursivas em que o sujeito se engaja, ou pode se engajar, as tendências que a língua pode manifestar quando o sujeito trabalha com os processos patológicos, exibindo a ação criadora (FRANCHI, [1977] 2002), que torna possível eleger processos alternativos no lugar da dificuldade e prosseguir como sujeito da linguagem (COUDRY, 2001, 2007; 2010; 2013). Interessante que isso seja possibilitado pela ação da atividade epilinguística, reflexiva, que sujeitos falantes experienciam com a linguagem desde os primeiros gestos de linguagem: balbucio, vocalizações, repetições, aproximações (COUDRY e BORDIN, 2012).

A metodologia que orienta esta pesquisa e que sustenta a ND é de base heurística e tem no processo seu foco de análise, onde são flagrados um conjunto representativo de dados-achados (COUDRY, 1996a; COUDRY e FREIRE, 2010), que ilumina tanto o olhar do investigador sobre o que investiga, como a teorização que lhe pode ser atribuída (de modo a movimentar a relação entre dado e teoria e vice-versa), quanto o olhar sobre a intervenção clínica/escolar.

A avaliação discursiva tem sempre algo de inesperado, que surge no próprio acontecimento discursivo e que escapa ao controle dos interlocutores, podendo ocorrer processos alternativos de significação que ocupam, por força da patologia, o lugar de processos já estabelecidos pela língua e seu uso e que foram esquecidos depois da entrada do sujeito na língua (COUDRY e BORDIN, 2012). Tais processos muitas vezes passam despercebidos do investigador no momento de sua enunciação e são retomados na análise dos dados e na escrita de caso (Cf. Nota 1). Na busca de desvendar essa trama, Coudry (1996a) propõe o conceito de dado-achado que tanto expõe os fatos linguísticos no processo em curso, quanto os torna objeto de reflexão, analisando-se seu papel nesse processo. Tal como o dado singular introduzido no estudo da aquisição da escrita por Abaurre, Fiad, Mayrink-Sabinson (1997), o dado-achado pressupõe um olhar minucioso, algo que, sendo único naquele momento do processo, ilumina o próprio processo, por onde transitam investigador e sujeito. $\mathrm{Na}$ avaliação e no seguimento longitudinal ocorrem dados singulares (ABAURRE e COUDRY, 2008) que mostram o percurso do sujeito e sua relação com a linguagem, movimento da teoria para o dado e viceversa, ou seja, indicam o modo de olhar para o dado e analisá-lo.

A seleção de um dado pressupõe, antes de tudo, uma mudança de papel: de clínico a investigador. $\mathrm{O}$ investigador se desloca do acontecimento discursivo (do então presente) para o evento discursivo (o passado/histórico) auxiliado pela visibilidade que o Banco de Dados em Neurolinguística (BDN) confere aos dados 
de linguagem. $\mathrm{O}$ clínico $^{12}$, por sua vez, está implicado na cena dialógica. E esse duplo papel pode estar na mesma pessoa. Deriva de um ponto de vista sobre o objeto (SAUSSURE, [1916] 1969). A retomada do acontecimento discursivo a posteriori requer do investigador um árduo trabalho de garimpagem dos registros em áudio e vídeo, bem como no diário de pesquisa, visando a transcrição de dados de linguagem e anotações das condições de sua produção no BDN, cuja configuração suporta tal materialidade (FREIRE e COUDRY, 2016). Exige, assim, uma atitude contemplativa do investigador: descentrar-se do momento da interlocução para nela achar uma boa explicação. Para tanto, o dado precisa ter visibilidade na complexidade de seu acontecimento; daí a relevância para os estudos neurolinguísticos do BDN como ferramenta metodológica que expõe as condições verbais e não verbais de produção do dado, ou seja, das práticas discursivas com as quais nos envolvemos. O BDN, portanto, não apenas auxilia o investigador na tarefa de transcrever dados, como também na busca e na identificação daqueles dados singulares e achados.

Faz sentido, nessa perspectiva, avaliar como o sujeito expressa sentidos e interpreta o jogo verbal de que participa como sujeito falante, levando em conta que o sentido não é dado previamente, mas se faz em meio a contingências enunciativas e ântropo-culturais (FRANCHI, [1977] 2002). Nesses termos, a questão da avaliação de linguagem em contextos patológicos insere-se no exercício de práticas significativas humanas e relaciona-se diretamente a situações de uso social da linguagem, diferentemente da abordagem tradicional, assentada em tarefas essencialmente metalinguísticas, descontextualizadas, baseadas em uma concepção normativa de língua e com uma única variedade legítima, a padrão (COUDRY, 1995; NOVAES-PINTO, 1992, 1999).

Considerar a avaliação como prática discursiva significa assumir que, do conjunto de atividades que se fazem com e sobre a linguagem, devem constar aquelas a que o sujeito tem sido exposto durante a vida, ou seja, as que o fazem transitar na relação da semiose verbal e não verbal com o social, com a vida em sociedade organizada em torno do que caracteriza a realidade humana: passamos a vida usando a língua em atividades orais e escritas que fazem sentido e quando ficamos afásicos... isso não pode faltar.

As afasias, por causarem modificações em várias esferas da atividade humana, sendo a principal a linguagem, afetam também a vida psíquica, o corpo, a percepção e a atenção, e provocam outra divisão no já cindido sujeito da linguagem (COUDRY, 2002). Aparece um sujeito estrangeiro, um outro eu, mais incompleto, que diz e faz coisas que não dizia/fazia (COUDRY, 2002). Quanto mais descontextualizadas são as atividades de linguagem propostas aos afásicos para avaliar suas dificuldades linguísticas, menos chances eles têm de conhecê-las e de enfrentá-las. E mais: eles estranham sua condição e o fato de sua linguagem e a dos outros ter mudado tanto. Por isso, desde nosso primeiro estudo discursivo das afasias (COUDRY, [1986] 1988),

${ }^{12}$ Linguistas que estudam a aquisição da fala, leitura e escrita partilham esse lugar, como também outros pesquisadores que se relacionam com sujeitos/participantes de pesquisas. 
nos posicionamos contra testes ${ }^{13}$ e práticas dirigidos a afásicos que os submetem a perguntas sobre a língua e a ordens verbais que não fazem sentido mesmo para não afásicos. Ficam prisioneiros de uma avaliação que condiciona respostas únicas e iguais para todos, contrariando a natureza simbólica e não transparente da linguagem e de seu jogo discursivo, até mesmo quando as cenas enunciativas acontecem (COUDRY, 2016, 2017; COUDRY e FREIRE, 2017a). Reflexão que se amplia para outras patologias da vida adulta e da infância.

\section{2. Sobre o Banco de Dados em Neurolinguística (BDN) ${ }^{14}$}

O BDN vem se desenvolvendo desde 1996 objetivando, especialmente, a transcrição, o armazenamento e a busca de dados produzidos em sessões individuais e em grupo do Centro de Convivência de Afásicos (CCA/UNICAMP) e do Centro de Convivência de Linguagens (CCazinho/UNICAMP). O funcionamento desses Centros ${ }^{15}$ (o primeiro voltado a afásicos, o segundo a crianças e jovens com dificuldades escolares, sobretudo de leitura e escrita, sendo a fala também considerada) se baseia em práticas discursivas verbais e não verbais que fazem sentido aos participantes que convivem entre si sistematicamente e que se reconhecem como um grupo de pessoas e como falantes de uma língua natural, por partilharem de parâmetros culturais comuns (hábitos, crenças, artefatos, dispositivos, etc. $)^{16}$.

${ }^{13} \mathrm{~A}$ ND considera a possibilidade de se avaliar a linguagem por meio de experimentos com sujeitos falantes, com e sem patologia, orientados por um saber técnico sobre a língua e a linguagem, envolvendo a fala, a leitura e a escrita, tal como várias pesquisas em Neurolinguística de tradição discursiva mostram (COUDRY, [1986] 1988, 1996a; 1996b, 2008, 2014a; NOVAES-PINTO, 1992, 1999; GREGOLINGUINDASTE, 1996; FREIRE, 1999, 2005; FLOSI, 2003; ANTONIO, 2011; COUDRY e BORDIN, 2012; MOUTINHO, 2014; MULLER, 2013; COUDRY e FREIRE, 2017a); sem que isso implique em avaliá-los negativa ou positivamente, nem diagnosticá-los a partir de tais experimentos.

${ }^{14}$ Este item é retomado com base em textos recém-escritos: Freire e Coudry (2016) e Coudry e Freire $(2016 ; 2017 \mathrm{a})$, em que revisitamos pontos centrais do BDN, articulando-o à avaliação discursivamente orientada que, exposta na tabela do BDN (COUDRY, 2001, 2003; CAMPETELA, 2002), dá visibilidade à cena enunciativa transcorrida e à cenografia que se estabelece (COUDRY, 2012, seguindo MAINGUENEAU, 2005).

${ }^{15}$ Todas as sessões são filmadas, decoupadas e anotadas em diários de pesquisa pelos investigadores que delas participam. Posteriormente, dez minutos de cada sessão são transcritos, de acordo com o BDN, por bolsistas SAE.

${ }^{16}$ Com base nos princípios teórico-metodológicos que sustentam a ND, o CCA dedica-se ao estudo da afasia e desenvolvimento de práticas com a linguagem, orientadas discursivamente, integradas na avaliação e acompanhamento longitudinal. Fazemos no CCA o que fazemos no mundo em que vivemos: falamos, lemos, escrevemos, jogamos, cozinhamos, passeamos, etc., visando a retomada da linguagem, em suas várias faces, em interação com outros interlocutores, afásicos e não afásicos. COUDRY (1996b, 2001, 2002, a;ba ) e MORATO et alii (2002) são textos que focalizam os princípios teórico-metodológicos, as práticas discursivas e a dinâmica de funcionamento do CCA. Seguindo tais princípios, no CCazinho é realizado um trabalho no eixo fala, leitura e escrita com crianças e jovens que apresentam dificuldades escolares, muitas das quais receberam diagnósticos neurológicos (relativos a: Dificuldade de Aprendizagem, Dislexia, Déficit de Atenção com ou sem Hiperatividade, Déficit no Processamento Auditivo, Déficit Intelectual) que produzem efeitos negativos em seus processos de escolarização e em suas vidas (COUDRY, 2006; BORDIN, 2010; ANTONIO, 2011; MULLER, 2013; MOUTINHO, 2014; RIGHI-GOMES, 2014; SILVA, 2014). A ND, considerando os dados dessas crianças, questiona tais diagnósticos, insere-as no CCazinho e no mundo das letras. Para detalhes sobre o CCA e o CCazinho, ver, especialmente, Coudry e Bordin (no prelo). 
Para retratar a dinâmica das situações dialógicas, o BDN dispõe de um sistema de notação e codificação, bem como de um sistema aberto de busca baseado em categorias descritivas para auxiliar a identificação de dados (COUDRY, 2001; FREIRE e COUDRY, 2016). Mais importante, como já foi dito, é o fato de dar a (re)conhecer aquilo que antes podia estar oculto, contribuindo para o refinamento teórico-metodológico das análises neurolinguísticas empreendidas (e do seguimento longitudinal), especialmente aquelas que envolvem a avaliação de processos de significação verbais e não verbais, que levam em conta $o$ funcionamento articulado da linguagem em níveis, bem como a relação da língua com outros sistemas semióticos.

Coudry (2001) e Campetela (2002) argumentam que há um processo cíclico que se volta para a elaboração do BDN, considerando que sua utilização por diferentes pesquisadores revela uma instabilidade necessária, constitutiva do movimento da teoria para o dado e vice-versa. É por essa mobilidade que o BDN não é apenas um depositário de dados, como também contempla categorias de descrição que são a base para pesquisas que incluem a análise de fatores nãoverbais para sua realização.

A tabela do BDN mais utilizada pelos pesquisadores é composta por seis colunas: (1) Código de Busca para permitir a seleção de certos enunciados; (2) Numeração das Linhas para facilitar a análise e a discussão dos dados; (3) Sigla do Locutor; (4) Transcrição propriamente dita; (5) Observações sobre as condições de produção do enunciado verbal; (6) Observações sobre as condições de produção do enunciado não verbal (20). Até que se chegasse à configuração de seis colunas, foram feitos vários ajustes em função das hipóteses teóricas dos estudiosos da área, por um lado, e das especificidades das práticas discursivas por eles utilizadas, por outro.

Conforme refletimos ao longo dos anos (COUDRY, 2001, 2003, 2007, 2013; FREIRE, 1999, 2005; FLOSI, 2003; FEDOSSE, 2000), dentre vários autores que realizaram sua pesquisa de iniciação cientifica, mestrado, doutorado, pósdoutorado, sob minha orientação, o BDN tem um papel preponderante no registro e na visibilidade do que ocorre na cena enunciativa em que transcorrem práticas discursivas que compõem uma versão protocolar. A avaliação é um lugar social, um lugar de exercício vivo de linguagem e de cidadania. É também um lugar de reflexão e de inquietude a respeito da realidade material do discurso, de coisa dita/ pronunciada e escrita, um lugar de comentário, de valor reparador/terapêutico, no sentido de expor o sujeito a diferentes fatos de linguagem e de cultura, que o fazem exercer diferentes papéis enunciativos, ocupar posições para dizer coisas ou deixar de dizê-las, para interpretar/compreender e ser interpretado/compreendido (COUDRY, 2001). 


\section{PATOLOGIZAÇÃO DE CRIANÇAS NORMAIS}

Em 35 anos avaliando crianças barradas em sua entrada para o mundo das letras, com dificuldades escolares, nunca me deparei com uma criança disléxica, de fato, mas, sim, com inúmeros diagnósticos - equivocados - de dislexia (COUDRY, 2014a; COUDRY, 2016; BORDIN e COUDRY, 2015; COUDRY e FREIRE, 2016; 2017b). Diagnósticos que não resistem ao enfrentamento das dificuldades da criança. É exemplar do despreparo para avaliar/diagnosticar a escrita do enunciado que consta em resultados de uma avaliação neuropsicológica: a criança troca letras na fala (que retomamos ao final deste texto).

A Neurolinguística Discursiva se posiciona radicalmente contra o discurso e a prática de avaliação conduzidos por profissionais que avaliam a linguagem sem conhecimentos técnicos, advindos da Linguística, e de seus estudos sobre língua (falada, escrita) e discurso. Em outras palavras, avaliam a linguagem sem, de fato, avaliá-la. Esse desconhecimento banaliza a avaliação e dispensa la crème de la crème da linguagem, para ficar com uma padronização idealizada que não a representa. Os efeitos disso são crianças que passam, na escola, e depois na clínica, por tarefas como ditados de palavras e de logatomas, exercícios de completar, cópias (do livro para a lousa e desta para o caderno), segmentação de palavras, atravessados por uma metalinguagem que acompanha o ensino da gramática, cuja compreensão pressupõe um domínio de escrita que a criança ainda não tem; e nessa toada não terá. Afásicos também passam por esses mesmos exercícios - ou semelhantes -, sem retomar a linguagem e seu funcionamento discursivo (COUDRY, 2014a).

A relação entre fala, leitura e escrita se mantém por toda a vida, sendo mais forte nos momentos em que o sentido não se realiza de pronto e que falar em voz alta e/ou escrever ajudam no seu reconhecimento. Uma forte relação entre letra e fala acontece com a soletração - que introduz sons novos para a criança (FREUD, [1891] 2010) - primeira condição para fazer referência à letra e entrar no sistema alfabético, compreendendo o funcionamento do sistema de escrita, pela sequência estável de letras que formam uma palavra. Saber soletrar uma palavra significa escrevê-la mantendo certas letras e apagando outras (COUDRY e FREIRE, 2005), o que acaba se tornando automatizado - isso porque, cerebralmente, tantas vezes os neurônios, em sinapses, percorrem um mesmo caminho que é facilmente recuperado, sem precisar pensar, o que corresponde ao encurtamento funcional descrito por Freud ([1891] 2010). É o que acontece ao ter aprendido a andar, falar, chutar bola, nadar. Soletrar ${ }^{17}$ é uma atividade metalinguística que incide sobre o escrever e não sobre a própria escrita, porque não se escreve diretamente o que se

${ }^{17}$ Muitos afásicos, como já mostraram autores clássicos (FREUD, [1891] 2010; LURIA, 1981, 1977) e, alguns dentre nós, Coudry ([1986], 1988, 2001, 2008); Flosi (2003); Santana, (2002); Freire (2005); Coudry e Bordin (2012) têm o sistema de escrita afetado pela afasia - esquecimento das letras, seu nome, sua forma, seu valor fonográfico, seu lugar na sílaba - e tem que refazer circuitos primordiais do sistema da escrita, e isso, na perspectiva da ND, se dá pela ação da tríplice aliança entre fala, leitura e escrita, ora com maior foco em uma, ora em outra, articulada com o que o gênero discursivo em questão convoca da língua e do discurso. 
soletra, mas há uma correspondência sonora e visual entre o nome e o som da letra e sua representação gráfica que é aprendida na vida escolar. É possível, entretanto, usar essa metalinguagem para passar à linguagem, como aconteceu na aventura entre mim e $\mathrm{GG}^{18}$, numa espécie de brincadeira que tem segredos a decifrar. Para fazê-la se concentrar em algo que lhe interessasse e conter a inquietação de seu corpo, propus que ela ia aprender a ler e escrever andando pelo IEL (Instituto de Estudos da Linguagem) e proximidades, com o objetivo de anotar de onde vinham os carros que frequentavam aqueles lugares, porque era um detetive com a missão de descobrir um roubo. GG aprendeu a soletrar, a ler e a escrever, soletrando, lendo e escrevendo em sua papeleta as placas dos carros. Aprendeu o nome de inúmeras cidades, as siglas do estados, números, e como são lidos, no caso de placas. E também os patronímicos (COUDRY, 2014a).

Por que o CCazinho inclui, de fato, as crianças no processo de leitura/escrita?

Pensamos (COUDRY, 2007; BORDIN, 2010; COUDRY e BORDIN, 2012; SILVA, 2014; RIGUI-GOMES, 2014; ANTONIO, 2011; FREIRE et alii, 2013; MULLER, 2013; BORDIN e COUDRY, 2015; COUDRY e BORDIN, no prelo) que a experiência do CCazinho tem dado certo por se ancorar em algumas frentes:

O sujeito é tomado em sua historicidade (considerando sua família, relações afetivas, características pessoais, gostos, sofrimentos, perdas, etc) e o acontecimento da aprendizagem, no caso da leitura/escrita, é indissociável da história do próprio sujeito, ponto de partida para novos caminhos. Por se tratar de atividades mediadas, não se perde de vista a ética que acompanha as práticas dos profissionais que lidam com essa população. O próprio sujeito é levado a conhecer seus processos de leitura e de escrita: quando acerta e quando erra, o que não entende, como é seu ritmo de aprender (VYGOTSKY, [1926] 2004, [1934] 2007) para dimensionar a importância da escola, da leitura e da escrita em sua vida. As atividades propostas e os dados que delas derivam são analisados em relação ao ponto do processo em que a criança se encontra, sendo crucial a manutenção do interesse e envolvimento por parte da criança e de seu cuidador ${ }^{19}$.

As atividades que desenvolvemos com as crianças contemplam o uso social que fazemos em nossa sociedade de práticas de leitura e de escrita e são incorporadas na relação social e afetiva que a criança vivencia com a escrita (COUDRY, 2007; BORDIN, 2010). Quando necessário, os conteúdos escolares são ressignificados nas experiências prévias e atuais do sujeito, e os termos metalinguísticos são desdobrados em relação ao sentido e a operações mais abstratas. Os critérios médicos que elencam as diferentes patologias são analisados pelos pesquisadores

\footnotetext{
${ }^{18}$ Fez parte desse processo a então doutoranda, na área de Análise do Discurso, Marcela Franco Fossey cujo acompanhamento longitudinal de GG, em 2010 e 2011, deu lugar a um conjunto de textos lidos e escritos em parceria, que a motivaram muito a entrar no mundo das letras.

${ }^{19}$ Definimos e formamos o aluno-cuidador à luz do ensinamentos de Vygotsky ([1926] 2004) para atuar na zona de desenvolvimento iminente de diversas práticas com a linguagem que envolvem a fala, a leitura e a escrita. Investimos na formação em linguagem do cuidador tendo a Linguística como eixo, além de outras áreas em que a relação eu/outro/Outro é constitutiva e incompleta. No intuito de investir, institucionalmente, na formação de tais alunos, é que se criou, em 2006, a disciplina AM 035 Ler e escrever: acompanhamento de crianças e jovens I, oferecida todos os semestres ímpares e $\mathrm{AM}-045$ Ler e escrever: acompanhamento de crianças e jovens $I I$, oferecida nos semestres pares.
} 
e tematizados com os sujeitos e suas famílias, e os resultados do aprendizado da leitura e da escrita avaliados. Nestas condições, os diagnósticos são discutidos em relação aos dispositivos (FOUCAULT, 1987; AGAMBEN, 2009) a que respondem, e não se confirmam.

Conforme analisamos em Bordin e Coudry (2015), a família é presença fundamental na vida escolar dos filhos. Aprendemos, no grupo de mães e nos contatos com as escolas, que a relação entre família e escola está desgastada, sendo preciso refazê-la. Foi o que nos propusemos a fazer no CCazinho ${ }^{20}$, reconhecendo a diferença entre esse centro e a escola: retomamos os processos de aprendizado escolar dos pais, compreendemos juntos os de seus filhos, com suas dificuldades e conquistas; lançamos desafios para a contribuição dos pais no processo escolar dos filhos, o que, por sua vez, tem um efeito positivo nas relações da família. Saber o que os filhos aprendem, poder acompanhar algumas lições de casa, ampliar suas experiências culturais com as de seus filhos tem sido uma vivência genuína que dá frutos na vida da família e, também, da escola. Diferentemente do CCazinho - um grão de areia no deserto da inclusão - a patologização a que estão submetidas as crianças que, por alguma razão, fogem de um padrão pré-estabelecido de aprendizado, tem excluído crianças normais de processos normais de aprendizado da leitura/escrita para, logo depois demandar sua inclusão (BORDIN E COUDRY, 2015). A situação da criança piora porque é incluída na Progressão Continuada ${ }^{21}$, a qualquer custo, sem o devido preparo dos profissionais que conduzem esse descaminho. Recusamos essa ordem de coisas que determina uma categoria patológica para a criança (Dislexia, Transtorno do Déficit de Atenção e Hiperatividade, Distúrbio/Dificuldade de Aprendizagem, Déficit Intelectual, dentre outras), por desconsiderar a sua relação com a leitura/ escrita. Em suma, as crianças que frequentam o CCazinho têm aprendido a ler com compreensão e escrever com sentido. Entram para o mundo das letras por diversos caminhos e em seus ritmos próprios, tal como sujeitos históricos que são.

\section{AFASIA E INFÂNCIA}

A relação entre afasia e infância aparece nos primeiros estudos discursivos da afasia (COUDRY, [1986] 1988), inspirados em Lemos (1982), nos quais Coudry identifica processos dialógicos na fala do afásico semelhantes aos que Lemos identifica na fala infanti122. Coudry e Bordin (2012) e Bordin e Coudry (2015) retomam radicalmente essa relação com base em Jakobson ([1941] 1980), Freud ([1891] 2010) e Heller-Roazen ([2005] 2010). Esses autores reafirmam que o afásico sai do sistema da língua (o que afeta a fala, a leitura e escrita) e nossos dados mostram suas tentativas de (re)entrar nesses sistemas. Por outro lado, a criança já dominando a fala, lugar do sentido para ela, tem esta como âncora

${ }^{20}$ Sonia Sellin Bordin se dedica ao estudo longitudinal do grupo de mães em seu pós-doutorado (de 2015 a 2017), no Departamento de Linguística, tema sobre o qual temos escrito em parceria.

${ }^{21}$ No caso do estado de São Paulo.

${ }^{22}$ Textos de referência: Coudry e Freire (2017b); Coudry e Bordin (no prelo). 
inicial para entrar no sistema alfabético. É interessante como a reflexão que 0 espaço da escrita possibilita tem efeitos na estabilização de relações de diferença no sistema (LURIA, 1977, 1981; POSSENTI, 2005; ALKMIM, 2009). A escrita se organiza pela ação da atividade epilinguística (CULIOLI et alii, 1970; COUDRY, [1986] 1988; COUDRY E BORDIN, 2012) que se desdobra em nossa intuição de sujeito falante. A comparação ${ }^{23}$ entre afasia e linguagem infantil que temos realizado, portanto, contribui fortemente para compreendermos as modificações advindas da afasia que afetam a escrita, por um lado, e o processo de entrada da criança no sistema alfabético, por outro.

Temos mostrado (COUDRY, 2010; COUDRY e BORDIN, 2012; FREIRE et alii, 2013) que a afasia desorganiza a base fonográfica que sustenta a escrita alfabética (FARACO, 2012) e, estando a criança em processo de automatizá-la, ambos passam por caminhos muito próximos, em um percurso marcado pela história do sujeito. Temos incluído a reflexão que Abaurre (2001) faz sobre a estruturação da sílaba em textos escritos por iniciantes, na reflexão sobre a escrita de afásicos, modificada pela afasia que desestrutura/dissolve sistemas e subsistemas automatizados ${ }^{24}$ : "a criança precisa decidir primeiro sobre o número de segmentos a serem representados e depois sobre a posição de cada um na estrutura da sílaba (o que descaracteriza o que se convencionou chamar de "troca de letras')" (ABAURRE, op. cit. p. 70-71).

Freud ([1891] 2010) vislumbra uma aproximação entre criança e afásico. Ele concebe a afasia como uma modificação funcional que interrompe os diferentes graus de intimidade que construímos pela vida com a linguagem (fala, leitura e escrita). Tal aproximação é baseada no conceito de dissolução proposto pelo neurologista H. Jackson ([1874] 1915), que caracteriza o estado afásico como uma impossibilidade para formar proposições e relacionar palavras, ou seja, produzir enunciados, ter iniciativa para falar (COUDRY, 2008).

Aprende-se com Jakobson ([1941] 1980) que o afásico retorna a caminhos há muito esquecidos e que a criança trilha por caminhos que serão apagados por constrições do sistema a que se submete em sua língua materna. E nesses caminhos se cruzam processos comuns para o afásico e o aprendiz de linguagem ${ }^{25}$, conforme demonstram Coudry (2010), Coudry e Bordin (2012), Coudry e Freire

${ }^{23}$ Também na fala há semelhanças entre a entrada da criança na língua e a desestruturação desse sistema pela afasia: simplificação de sílabas complexas, diferenças não concluídas entre traços, imprecisão articulatória, gestos que se desautomatizam/não se automatizam, primazia do nome na iniciativa verbal para depois expandir as relações dele com outras palavras, anterioridade da seleção sobre relações de contiguidade, não reversibilidade de papéis discursivos, não especificação morfológica e produção de unidades sem sentido formadas de combinações possíveis no sistema da língua (correspondência entre tatibitate na aquisição e jargão indiferenciado na afasia). É interessante articular esse paralelismo com aquele que muitos linguistas já apontaram quanto à semelhança entre processos de aquisição de fala e de escrita (ABAURRE, 2001), exemplarmente a preferência pela sílaba canônica, a hesitação diante da coda, a inserção e apagamento de letras às voltas com a ordem de segmentos na sílaba.

${ }^{24}$ Sistemas funcionais complexos, conforme Luria $(1977,1981)$, e que não podem ser lembrados/ associados, pelas modificações no aparelho de linguagem, conforme Freud ([1981] 2010).

${ }^{25}$ Isso não significa que o afásico deva ser tomado como teimoso, tendo perdido a possibilidade de linguagem, sobretudo tratado como criança. Este último aspecto infantiliza a relação do sujeito com a linguagem e o outro e é ainda comum hoje propor tarefas descontextualizadas, escolarizadas e infantilizadas que o distanciam ainda mais do exercício da linguagem e, consequentemente, da possibilidade de reconstrui-la como sujeito da linguagem. Para maiores detalhes, ver Labigalini (2009). 
(2016). Dados de escrita de crianças e afásicos têm mostrado essa aproximação: i) a busca pela posição das letras em sílabas complexas (ABAURRE, 2001) é um lugar de encontro para os dois grupos que hesitam e oferecem escritas possíveis e aproximações diante do preenchimento ou não de certas posições; ii) o movimento da escrita para a fala e vice-versa; iii) o apoio na soletração para escrever; iv) o ajuste da fala à leitura do que escreve, seja omitindo ou inserindo segmentos na escrita ou na leitura (AMARAL et alii., 2011); v) o ritmo da escrita e o ritmo da fala (CHACON, 1998). O que o sujeito faz no lugar do que deveria fazer é o que interessa saber no caso da escrita do afásico e do aprendiz de escrita.

Temos estudado a relação afasia/dissolução e infância/aquisição e investido na análise da relação entre escrita e ritmo (ABAURRE, 1991, 2003; BARBOSA, 2013; MIGLIORINI e MASSINI-CAGLIARI, 2010) que afásicos e iniciantes das letras usam para ler o que escreveram. Apresento dados de três sujeitos do estudo que compartilhei com Freire em 2016 para, em seguida, apresentar dados da proximidade entre afasia e escrita infantil.

\section{1. Sujeitos de um estudo experimental}

RF, sexo masculino, nasceu em 12/02/2008 e começou a frequentar o CCazinho no $2^{\circ}$ semestre de 2015 , por intermédio de um primo que também frequenta o Centro. RF está no $3^{\circ}$ ano do Ensino Fundamental, estuda no período da tarde e frequenta aulas de reforço na escola duas vezes por semana. No dia do seu primeiro acompanhamento em 2016, no CCazinho, RF disse que a atividade da aula de reforço tinha sido escrever várias vezes o alfabeto em letra cursiva maiúscula e minúscula.

A pediatra de RF solicitou exames auditivos por entender que o seu quadro sugeria Doença do processamento auditivo, já que a criança apresentava dificuldade escolar desde o início da vida escolar. A audiometria, datada de junho de 2015, mostrou-se sem alterações, mas a avaliação do Processamento Auditivo concluiu, após a aplicação de seis testes realizados em uma única sessão, na qual $a$ criança se manteve atenta, que ela apresenta essa desordem, do tipo Decodificação e Prosódia.

Observamos que RF, como a maioria dos aprendizes, escreve como fala e não ortograficamente; o importante é que faz hipóteses para escrever como escreve e lê como escreve mostrando suas hipóteses, como seus dados mostram: escreve norman para "normal" e outras instabilidades (formas diferentes das fixadas pela ortografia) na representação da coda na sílaba medial ou final: "barril" é escrito como barin, baril e, finalmente, barri; "calda" é escrito como cáda; "voltou" como voltou.

GF, um dos afásicos do nosso estudo, é um jovem de 23 anos, destro, e apresenta uma afasia verbal (FREUD, [1891] 2010) acompanhada de uma hemiplegia à direita, decorrente de um traumatismo cranioencefálico, por atropelamento, em setembro de 2010. GF chegou ao CCA no $1^{\circ}$ semestre de 2012 e, durante a avaliação, falou pouco e, em alguns momentos, recorreu à escrita e a gestos. Quando perguntamos sua idade, mostrou o dedo indicador e médio para 
dizer o número 2. Em seguida, a investigadora lhe deu um papel e GF escreveu 19 e também o 2, querendo dizer que tinha 19 e estava para completar 20 anos.

GF passou por uma craniotomia, em que se constatou lesão nos lobos frontal, temporal e parietal no hemisfério esquerdo. Na época, frequentava o $3^{\circ}$ ano do Ensino Médio no período noturno e trabalhava durante o dia em uma empresa. GF tem apresentado melhora em sua fala e também na leitura/escrita. A leitura, como a fala, está lentificada, em um ritmo mais silábico do que misto, com efeitos na prosódia, conforme descrito na literatura (ABAURRE, 2003; MIGLIORINI e MASSINI-CAGLIARI, 2010; CAGLIARI, 1989; CAGLIARI, 2012, 2013; MASSINI-CAGLIARI, CAGLIARI, 2001; BARBOSA, 2013); a escrita apresenta episódios constantes de refacção (ABAURRE, et alii, FIAD, MAYRINK= SABNSSEN, 1997) e de autocorreção, que voltam para a fala de novo. Fala, leitura e escrita se alimentam uma da outra nesse momento. Além de frequentar o CCA, GF estuda em uma escola do município em que mora, onde cursa o Ensino de Jovens e Adultos (EJA).

BC é também um jovem afásico, de 29 anos, destro, e apresenta uma afasia verbal (FREUD, [1891] 2010) devido a um Acidente Vascular Encefálico Isquêmico (AVEi, ocorrido em julho de 2012, em função de uma dissecção da carótida por um problema congênito. Como sequelas do AVEi, BC apresenta hemiparesia direita de membro superior e inferior e afasia por lesão têmporoparietal esquerda. Seu quadro afásico inicial se caracterizou por uma estereotipia que ocupava o lugar das palavras, além de dificuldades de leitura e escrita. Embora já tenha apresentado progressos significativos, sobretudo na fala, ainda revela uma escrita permeada de paragrafias, marcada por episódios de refacção (ABAURRE, et alii, FIAD, MAYRINK-SABINSON, 1997; ABAURRE, COUDRY, 2008), nos quais ele se autocorrige até reescrever a palavra ortograficamente.

A seguir, apresento dados dos afásicos (GF e BC) e da criança (RF) na tentativa de escrever e ler as palavras "exclamou", "sugestão" e "imensa" que apresentam lugares de complexidade para serem escritas: sílaba complexa, ortografia e representação nasal, o que vem sendo tomado como sintoma de patologia. 


\section{2. Dados}

Dado 1: Escrita da palavra "exclamou"

\begin{tabular}{|c|c|c|}
\hline RF & GF & BC \\
\hline esglamou & esclamou \\
& ezcl*26 & exclamou* \\
& escri & \\
& classe & \\
\hline es-cla-mo- $u$ & esclasse & es-cla-mo \\
\hline
\end{tabular}

Fig. 1

Fig. 2

Fig. 3

RF e GF ajustam a fala à escrita ao lerem em voz alta a palavra, para dar relevo ao som final $u$, lugar em que ambos hesitaram na escrita, uma vez que, como muitos falantes, nenhum deles na fala espontânea sonoriza essa coda silábica (exclamo), exatamente como BC lê sua produção final. RF e GF leem es-cla-mo-u. A escrita, portanto, orienta a fala com a qual leem o que escreveram; ambos inserem um segmento na leitura que fazem. Um ponto comum entre todos é que se orientam foneticamente (e não ortograficamente) para escreverem a palavra "exclamou": usam o /s/ no lugar da letra " $\mathrm{x}$ " que tem várias representações sonoras.

Vejamos separadamente o que cada um faz. A escrita de RF revela a instabilidade do traço que marca a sonoridade na escrita (exglamou), que não se revela na fala. $\mathrm{O}$ modo de ler a palavra mostra como a criança de uma variedade não padrão chega a uma fala cuidada, mais próxima à escrita ortográfica. $\mathrm{O}$ alongamento da fala de RF para se ajustar às letras dispostas no papel, provavelmente, é motivado pela ideia de que há uma correspondência direta entre o que escreve e o que lê, o que desaparecerá à medida que o processo avança e

${ }^{26}$ As produções escritas marcadas com asterisco $(*)$ são reescritas após a leitura da própria produção; as demais são tentativas de aproximação da palavra-alvo realizadas antes da leitura em voz alta. As palavras em itálico, na última linha da tabela, correspondem à leitura em voz alta realizada pelos sujeitos após a escrita final da palavra. 
que ele passa a ler palavras e não mais se apoia em seus segmentos que, no início, decompõe soletrando e recompõe escrevendo unidades de sentido, palavras da língua.

GF, ao escrever "exclamou", se apoia no modo como fala a palavra: escramou, o que resulta na sua primeira tentativa de escrita (escri). Interpelado pela investigadora para dizer uma palavra com a sílaba cla, diz e escreve classe, o que motiva a paragrafia esclasse e, finalmente, escreve exclamou.

$\mathrm{BC}$ escreve foneticamente a palavra (esclamou) e a lê como a diz espontaneamente, recorrendo ao velho da língua (COUDRY, 2008, seguindo FREUD, [1891] 2010). Interpelado pela investigadora sobre a ortografia convencional da palavra apresenta dificuldade para registrar a letra " $x$ " - que na primeira tentativa se aproxima de um " $z$ " -, até atingir uma forma mais próxima à grafia da letra-alvo, talvez pela dificuldade motora que apresenta.

Abaurre (2003) nos dá argumentos interessantes para analisar a leitura de palavras pela criança e pelo afásico: reconhecer no ritmo um lugar de (re) organização, tanto da fala quanto da escrita, em seus vários níveis de estruturação. Ler silabicamente provoca uma certa ordem no intervalo entre os constituintes lidos que coincide com o número de dois caracteres $(\mathrm{CV})$ e ao final da palavra não pode sobrar nenhum deles sem ser falado, como se houvesse um pareamento entre o escrito e o falado. Ambos, criança e afásico, alongam a fala para corresponder aos caracteres ${ }^{27}$.

Também a reflexão de Cagliari (2013) sobre ritmo ajuda a compreender esse fenômeno: a criança que ainda não domina a escrita e o afásico que deixa de dominar conferem um ritmo silábico à fala quando leem. É como se afásico e criança lessem todas as letras da palavra em um ritmo silábico, lexical, de forma diferente de como a pronunciam na fala, separada de sua forma gráfica e articulada a outras palavras, pós-lexicalmente, configurando um ritmo acentual para o Português do Brasil (PB), conforme analisam o autor e as autoras Migliorini e Massini-Cagliari (2010).

A atividade linguística de escrever palavras dá lugar a uma atividade epilinguística que se cruza com uma reflexão de natureza metalinguística na tentativa de desvendar a própria escrita. Por outro lado, estudos de AbaurreGnerre (1981) e Abaurre (2003) argumentam a favor de um ritmo misto para o PB, assim como Bisol (2000) e Barbosa (2000). Barbosa (2013) reanalisa a questão e apresenta vários argumentos para considerar o PB como uma língua acentual, havendo certos contextos em que um ritmo silábico pode acontecer, como nossos dados mostram.

Mesmo considerando o PB uma língua de ritmo acentual, pode acontecer um ritmo silábico, conforme pontua Abaurre-Gnerre (1981), em uma fala mais formal ou mais lenta, tal como ocorre com (re)aprendizes de escrita. É como se a duração das sílabas servisse à leitura vozeada para corresponder às unidades gráficas. Com a automatização da escrita/leitura, a duração das sílabas é fixada, com valores

${ }^{27}$ Tal como muitos professores de anos iniciais fazem na tentativa de parear a relação som/letra, especialmente em atividades como o ditado. 
determinados pela língua, conforme indica Cagliari (2013), o que a criança já faz em relação à fala e o afásico também (desde que não apresente dificuldades articulatórias que intervenham em sua fala), embora possa haver alguma hesitação tanto de um quanto de outro em palavras desconhecidas ou não reconhecidas. Barbosa (2013) retoma a concepção de ritmo da escrita definido por Abaurre (1991), relacionado 'ao modo como um texto 'respira' depois que o gesto rítmico com o qual foi produzido se 'congela' em signos gráficos sobre uma página em branco" (BARBOSA, op. cit. p. 78). A reflexão de Barbosa (2013) quanto ao papel do novo (escrita) no ritmo da fala fortalece o modo como encaminhamos o experimento de leitura do que a criança e os afásicos escreveram: leitura e escrita que se (re)estruturam no novo aprendizado, sendo o ritmo o item marcado nesse processo.

Em nossa pesquisa, observamos que a criança que ainda não domina a relação entre gestos articulatórios e sua representação gráfica, e o afásico, que volta a se encontrar na mesma condição, não têm essa relação automatizada: deslizam no controle pneumofônico e ajustam a leitura a uma fala silabada para destacar certos aspectos da palavra escrita. Observamos, ainda, que mesmo o afásico escolarizado, com conhecimento formal do que é uma palavra e uma sílaba, e a criança lidando, intuitivamente, com a sílaba como unidade de fala, ambos funcionam da mesma forma nessa espécie de leitura inicial da unidade da escrita, a palavra.

\section{3. Outros dados de afásicos e de crianças}

\section{Dado 2: Escrita da palavra ombro}

Como as crianças também fazem, o afásico $\mathrm{PP}^{28}$ representa a coda da sílaba VC de ombro como umebro ${ }^{29}$ em que não hesita sobre a posição da primeira vogal, mas o que a acompanha, recorrendo ao que lhe é mais estável, a representação CV, em que insere uma vogal ao lado da consoante.

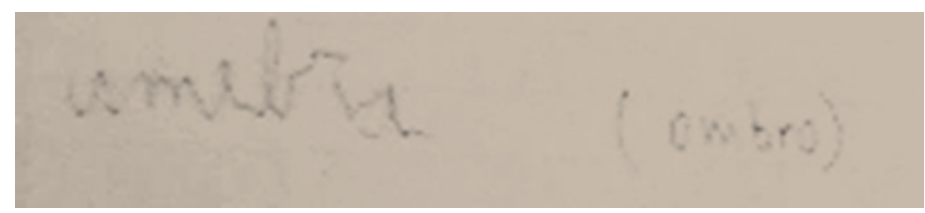

Fig. 4. Ombro/umebro (Fonte: Banco de Dados de Neurolinguística - BDN - CNPq: 312522/2013-4)

${ }^{28}$ Apresenta uma afasia verbal (FREUD, [1891] 2010) que dificulta a produção da fala e seu ajuste ao sistema fonológico.

$\underline{29}$ Há nessa palavra, características comuns da escrita inicial: a letra $o$ é escrita como u, sendo a escrita mais vulnerável à ação da fala, o que interfere na pronúncia de várias palavras, e isso é generalizado pela criança; o traçado da letra $o$ se assemelha ao da letra $a$, além da epêntese vocálica para corresponder ao padrão canônico $\mathrm{CV}$. 


\section{Dado 3: soletração}

Um dado de um afásico, $\mathrm{GM}^{30}$, que tem a base fonográfica da escrita afetada pela afasia (e a soletração dá visibilidade a esse empecilho), no primeiro dia em que começou a frequentar o CCA, depois de o grupo entrevistá-lo e cada um falar um pouco de si, passamos a soletrar nossos nomes próprios e ele soletrou o dele (GEREMIAS) assim: a primeira sílaba (GE, E) e depois completou dizendo REMIAS, mostrando que a decomposição da escrita em unidades mínimas e sua recomposição na palavra é uma dificuldade para ele e que a leitura está implicada nesse processo.

Ele escreve seu nome, mas não o soletra. O nome das letras e a soletração de palavras é uma questão para a afasia: GM sabe o nome das letras, uma por uma, mas não soletra a palavra, nem para escrevê-la. Na tentativa de soletrar a palavra computador, ele desenhou no ar, com o dedo, a letra $\mathrm{C}$, falando seu nome, depois disse o $\mathrm{O}$, o $\mathrm{P}$, o U e, finalmente, computador, retomando a palavra inteira, sem ter terminado a soletração. Para a palavra bolo, soletrou: B, O, bolo. Sem pertencer a regiões geográficas cujos falantes soletram integrando sílaba por sílaba, ele não se desvencilha da palavra por inteiro. Segmentar a palavra em unidades menores e recompô-las em unidades maiores para escrever a palavra por inteiro é um ponto em que incide sua afasia. Logo que começa a soletração, ele insere o que está faltando sem soletrar. Soletrou muito bem óculos como OCLOS, e falou várias vezes oclos (tal como muitos de nós falamos), recorrendo à fala para escrever, o que as crianças também fazem. No caso de GM, é como se a afasia apagasse uma das portas de entrada da leitura/escrita, o nome das letras, matéria prima da soletração, que dá lugar à escrita da letra na palavra e à estabilização da sequência de letras que formam a palavra.

GG, uma das crianças do estudo de Coudry (2014a), com 8 anos, diagnosticada com Dificuldade de Aprendizado, aprendeu a ler, lendo placas de carro, soletra abacaxi como ABKXI porque ainda não sabe que escrever a letra dentro da palavra é diferente de soletrá-la e, isso, faz parte do processo normal de aprender a ler/escrever. Um afásico poderia fazer a mesma coisa - como também uma criança, às voltas com a representação escrita da sílaba e com o modo como se escreve o nome das letras na palavra, - soletrar seu nome como Geremias o fez.

\section{NOTAS SOBRE A METODOLOGIA}

Decorridos mais de 30 anos do Diário de Narciso, a metodologia é uma questão presente em nossa reflexão e nos indaga sobre nossa própria prática de investigação e atuação. Relaciona-se com a produção dos dados e com sua análise, interpelada pela escrita de caso, que envolve movimentos teórico-metodológicos.

${ }^{30} 73$ anos, curso superior, apresenta infartos lacunares isquêmicos, configurando uma lesão difusa (indicativa de um processo em curso), em que se identificam sintomas de afasia que afetam sobretudo a escrita, especialmente depois do último episódio neurológico. 
Para a ND, o encontro com os sujeitos se dá pela linguagem, nossa estrela guia para compreender o funcionamento patológico e o normal, e seu exercício em práticas linguageiras/discursivas com as quais os sujeitos se envolvem, afirmando sua historicidade e tendo as dimensões semântica e semiótica atuando na função simbólica. Trata-se de práticas que veiculam várias formas de atuar na linguagem: diálogo, narrativa, comentário, discurso argumentativo, de opinião, de humor, entre outras. Práticas que materializam o que se fala/escreve no presente em que vivemos, veiculadas em jornais falados, escritos e na mídia eletrônica/internet/ redes: comentários sobre a política regional e nacional, com destaques para alguns acontecimentos no mundo; sobre os campeonatos de futebol que estão em curso, sobre culinária; sobre pessoas e suas histórias; enfim, realizando o traço primordial que Benveniste ([1969] 1995b) apontou para diferenciar a linguagem humana da comunicação animal: falar a outros que falam - o que para nós também pressupõe escutar o outro e a si mesmo, e inevitavelmente ver (um sistema aberto nos termos de FREUD, [1891] 2010), considerando o mundo visual em que vivemos. Jogamos com a linguagem, por exemplo, quando brincamos de acesso a nosso léxico mental/linguístico por meio de palavras que começam por " $\mathrm{x}$ " (uma determinada letra); fazemos experimentos com a linguagem quando propomos a escrita de uma história a partir de seis palavras, para observar o papel dessas palavras e da fala na organização da escrita, para cada sujeito; as marcas de subjetividade que aparecem no texto mesclando a história a ser contada com a vida pessoal; quando propomos que deem título a uma manchete de jornal do dia, escondendo a original, para depois compararmos entre todos. Em seguida, cortamos as palavras da manchete para que a reconstruam e as comparamos.

Tal posição metodológica frente aos dados tem efeitos na teorização e em seu refinamento, inaugurando novos movimentos entre teoria e dado. $\mathrm{O}$ dadoachado, peça fundamental dessa metodologia, instiga que outros aportes teóricos sejam incorporados à ND e pode motivar, porque ilumina o ponto em que se está, experimentos com a linguagem, envolvendo estruturas e processos.

Tal metodologia, de natureza heurística, supõe um olhar histórico, por um lado, e singular ${ }^{31}$, por outro, e assenta-se em processos e procedimentos de descoberta, que se estabelecem ao longo do acompanhamento longitudinal e demandam do investigador uma atitude de aproximação e distanciamento, que possibilita a compreensão das dificuldades dos sujeitos e das soluções que encontram, mesmo que por caminhos solitários (COUDRY, [1986] 1988, 1996b, 2001, 2007, 2010, 2016; COUDRY e FREIRE, 2010; BORDIN e COUDRY, 2015; COUDRY e FREIRE, 2016, 2017; FREIRE e COUDRY, 2017; COUDRY e BORDIN (no prelo) e/ou transitórios que, muitas vezes, não podem ser repetidos, lembrados.

${ }^{31}$ A leitura de Birman (2012) e de Forbes (2102) me leva a considerar que, hoje em dia, no mundo horizontal em que vivemos, o singular se junte com outros singulares, o que torna plural e compartilhadas as funções e papéis que exercemos. A relação em rede aproxima pessoas, identifica pessoas, e isso pode ter efeitos bons ou ruins para os envolvidos. 


\section{PALAVRAS FINAIS}

Para finalizar este escrito, que abre as portas para a nova etapa do Projeto Neurolinguística Discursiva: Afasia e Infância e, compreendendo o tempo presente, conforme Birman (2012), seguimos Forbes (2012) que indica uma correlação ${ }^{32}$ entre a lógica do $\mathrm{DSM}^{33}$ IV e o progresso da indústria psicofarmacológica. Isso tem sustentado o fracasso escolar e o excesso de diagnósticos atribuídos a crianças que estão em processo de decifrar e experimentar a escrita como algo além de sua fala e da de outros.

Tal realidade é perversa e o papel de denunciar/informar de várias formas e em vários ambientes é constitutivo de uma ND responsável ${ }^{34}$, tal como a concebemos. O que chamamos de uma Neurolinguística Responsável (de responsabilidade), conforme Forbes (2012), implica em considerar a contemporaneidade (BIRMAN, 2012; FORBES, 2012; COUDRY, 2014b) que se estabelece horizontal e espacialmente em redes e, no nosso caso, um saber técnico que se sustenta na articulação de autores que estudam a linguagem, a afasia e a infância, e em seus efeitos em várias práticas científicas: formação profissional, seguimento longitudinal de afásicos e de crianças com dificuldade de viver a letra na escola $\mathrm{e}$ divulgação (oral e escrita) do que temos formulado e praticado. Responsável pelas escolhas que fazemos, dentre as milhares que se apresentam - esse é um novo mal estar, lugar de angústia, de nossa civilização, no século XXI (FORBES, 2012).

Enfrentar a patologização significa ter contato com um desconhecimento técnico sobre a linguagem, em várias de suas dimensões, funções e registros que tem impregnado os diagnósticos que temos recebido. Confunde-se som com letra; o falado é tomado como erro na escrita de iniciantes (RIBEIRO, 2001; ALKMIN, 2009) e em processos intermediários (COUDRY, SCARPA, 1985; ABAURRE e COUDRY, 2008) que ocorrem antes do registro estável da escrita; desconhece-se a hierarquia dos constituintes silábicos, de como a sílaba se estrutura (ABAURRE, 2001), o que leva a aparecer na avaliação pérolas como: "a criança troca letras na fala" para se referir a um sintoma de patologia quando, entretanto, trata-se de dados de momentos variados do processo.

Que consequências há na escolaridade considerar, conforme Birman (2012), que a experiência da subjetividade na atualidade é marcadamente espacial, fugaz, que não se retoma? A falta da temporalidade - que correlaciona, diferencia, ordena e reordena, repete, transforma, etc. - tem efeitos na pouca experiência de narratividade que as crianças mostram hoje. Contar algo para alguém e contextualizá-lo em função de um diálogo que se estabelece, por exemplo, é uma experiência quase nula nesse momento da infância e acaba prosseguindo

${ }^{32}$ Que pode também valer para o DSM V, de 2013.

${ }^{33}$ Manual Diagnóstico e Estatístico de Transtornos Mentais.

${ }^{34}$ Linguística e Fonoaudiologia formam uma parceria que integra minha vida acadêmica como orientadora, logo em seguida a meu doutorado (1986) e nesses trinta anos que dele decorrem. O olhar da diversidade, da diferença (Linguística, Fonoaudiologia, Medicina, Neuropsicologia, Pedagogia, Psicologia) participa da ND desde seus primeiros movimentos, envolvendo o IEL e o Instituto de Biologia, desde os anos 70 do século XX. 
assim nos anos escolares. A experiência de escutar essas crianças, barradas na temporalidade, me levou a considerar a narrativa como uma forma de atuar no mundo em que a categoria tempo se impõe pela incidência do discurso dirigido a um outro e considerando a primazia do interdiscurso na discursividade que nos constitui (COUDRY, 2014b). No entanto, como o interlocutor está representado na escrita (ABAURRE, et alii, 1997; FARACO, 2012), demanda outras formas de contextualização, o que deveria ser parte do processo de entrar para o mundo das letras e não um empecilho. Mas o que se vê no caderno escolar das crianças que frequentam o CCazinho, sobretudo de escolas públicas, são ainda cópias e mais cópias, além de exercícios metalinguísticos com foco na gramática normativa, em expansão de vocabulário, por exemplo. Nenhum texto escrito pelas crianças com intervenção da professora para ser reescrito (COUDRY, FREIRE, 2005; POSSENTI, 2005), como tantos outros linguistas já apontaram.

A experiência de falar, ler, escrever no CCazinho tem mostrado que as crianças vão muito além do que se esperaria delas, não confirmando diagnóstico de patologia/distúrbio/alteração, etc. que afetaria a escrita/leitura, e aprendem o que se ensina para elas, em um ritmo próprio, como ocorre com cada um de nós. É como projetamos inventar o presente.

Para além de avaliações psicométricas, padronizadas para sujeitos que não existem, a experiência de linguagem no CCA tem mostrado que há do que falar, ler e escrever nas afasias, nas diversas atividades linguageiras/práticas discursivas que travamos, considerando os discursos prévios que nos habitam e a singularidade de cada um de nós. É como projetamos inventar o presente.

\section{REFERENCIAS}

ABAURRE-GNERRE, M. B. Processos fonológicos segmentais como índices de padrões prosódicos diversos nos estilos formal e casual do português do Brasil. In: Caderno de Estudos Linguísticos, 2: $23-34,1981$.

ABAURRE, M. B. M. Ritmi dell'oralità e ritmi della scrittura. In: ORSOLINI, M.; PONTECORVO. C. La costruzione del testo scritto nei bambini. Roma: La nuova ltalia, p. 77-98, 1991.

ABAURRE, M. B. Dados da escrita inicial: indícios de construção da hierarquia de constituintes silábicos? In: HERNANDORENA, C.L.M. Dados da escrita inicial: indícios de construção da hierarquia de constituintes silábicos?. Pelotas: EDUCAT/ ALAB, p. 63-85, 2001.

ABAURRE, M. B. Ritmo e linguagem. In: ALKMIN, T. COUDRY, M. I. H.; POSSENTI, S.; (Orgs.). Saudades da Língua. Campinas: Mercado de Letras, p. 85-94, 2003.

ABAURRE, M. B. M., COUDRY, M. I. H. Em torno de sujeitos e olhares. Estudos da Língua(gem). Vitória da Conquista, v. 6, n. 2, p. 171-191, dez. 2008.

ABAURRE, M. B., FIAD, R. S., MAYRINK-SABINSON, M. L. Cenas de aquisição da escrita. Campinas: Mercado de Letras, 1997. 
AGAMBEN, G. O que é contemporâneo? E outros ensaios. 1ª ed. Chapecó, SC: Argos, 2009.

ALKMIM, T. M.. Língua portuguesa. Objeto de reflexão e de ensino. Cefiel/IEL/Unicamp, 2009.

AMARAL, A. S., FREITAS, M. C. C., CHACON, L., RODRIGUES, L. L. Omissão de grafemas e características da sílaba na escrita infantil. Revista CEFAC, v. 13, nº 5, p. 846-855, 2011.

ANTONIO; G. D. R. Da sombra à luz: a patologização de crianças sem patologia. Dissertação Mestrado em Linguística. Campinas: IEL/UNICAMP, 2011.

BARBOSA, P. Syllable-timing in brazilian portuguese: uma crítica a Roy Major. In: D.E.L.T.A., vol. 16, n. $^{\circ} 2,369-402,2000$.

BARBOSA, P. Ritmo da escrita e ritmo da fala: congruências e não congruências. Domínios de Lingu@ gem. v.7, n, 2 , p. 47-70, 2013. Disponível em: http://www.seer.ufu.br/index.php/dominiosde linguagem.

BENVENISTE, E. Os níveis de análise linguística. In: BENVENISTE, E. Problemas de Linguística Geral I. $4^{\text {a }}$ ed. Campinas, SP: Pontes, p. 127-140, 1995a. (Data do original: 1969).

BENVENISTE, E. Comunicação animal e linguagem humana. In BENVENISTE, E. Problemas de Linguística Geral I. $4^{\text {a }}$ ed. Campinas, SP: Pontes, p. 60-67, 1995b. (Data do original: 1969).

BIRMAN, J. O sujeito na contemporaneidade. 1ª ed. Rio de Janeiro: Civilização Brasileira, 2012.

BISOL, L. O troqueu silábico no sistema fonológico. In: D.E.L.T.A., São Paulo, v. 16, n. 2, 2000.

BORDIN, S. M. S. Fala, leitura e escrita: encontro entre sujeitos. Tese de Doutorado em Linguística. Campinas: IEL/Unicamp, 2010.

BORDIN, S. M. S., COUDRY, M. I. H. Excluir para depois incluir In: BARROS, R. C. B., MASINI L. (Orgs.) Sociedade e Medicalização. v. 1. Campinas: Pontes Editores, p.129-146, 2015.

CAGLIARI, L. C. Alfabetização e Linguística. São Paulo: Ed. Scipione, 1989.

CAGLIARI, L. C. Algumas questões de linguística na alfabetização. Conteúdo e didática da alfabetização. São Paulo: UNIVESP, p.71-83, 2012.

CAGLIARI, 1. C. Existem línguas de ritmo silábico? Estudos Linguísticos. São Paulo, 42 (1): p. 19-32, jan-abr, 2013.

CAMPETELA, C. O Banco de Dados em Neurolinguística na relação dado/teoria. Anais do XXXI Seminário do Gel, 2002. Disponível em: http://www.gel.org.br/estudoslinguisticos/volumes/31/ $\mathrm{htm} /$ comunica/CCII8b.htm.

CANGUILHEM, G. O normal e o patológico. Rio de Janeiro: Forense Universitária, 1995. 
CHACON, L. Ritmo da escrita: uma organização do heterogêneo da linguagem. São Paulo: Martins Fontes, 1998.

COUDRY, M. I. H. Diário de Narciso: avaliação e acompanhamento longitudinal de linguagem de sujeitos afásicos de uma perspectiva discursiva. Tese de Doutorado em Linguística. Campinas: IEL-UNICAMP, 1986.

COUDRY, M. I. H. Diário de Narciso: discurso e afasia. São Paulo: Martins Fontes, 1988.

COUDRY, M. I. H. Princípios protocolares de avaliação neurolinguística. Estudos Linguísticos, São Paulo, v. XXIV, p. 174-178, 1995.

COUDRY, M. I. H. O que é dado em neurolinguística?. In: CASTRO, M. F. C. (Org.) O Método e o dado no estudo da linguagem. $1^{\text {a }}$ ed. Campinas, SP: Editora da Unicamp, p. 179-192, 1996 a.

COUDRY, M. I. H. Fontes de postulados teórico-metodológicos do Centro de Convivência de Afásicos (CCA). Estudos Linguísticos, Marília, v. XXV: p. 439-444, 1996 b.

COUDRY, M. I. H. - Projeto Integrado em Neurolinguística: avaliação e banco de dados. Relatório de Pesquisa, CNPq: 521773/95-4, de 1999 a 2001. Campinas, SP, 60p. Unpublished manuscript, 2001.

COUDRY, M. I. H. Linguagem e Afasia: uma abordagem discursiva da Neurolinguística. Cadernos de Estudos Linguísticos, Campinas, v. 42, n. 1, p. 99-129, Jan./Jun. 2002 a.

COUDRY, M. I. H. Clássico é clássico e vice-versa. Prova Didática apresentada para Concurso de Livre Docência, na área de Neurolinguística, no Departamento de Linguística do Instituto de Estudos da Linguagem da Universidade Estadual de Campinas, 54p. Unpublished manuscript, 2002 b.

COUDRY, M. I. H. Registro de linguagem, gestos e percepção no Banco de Dados de Neurolinguística. $51^{\circ}$ Seminários do GEL, 2003, Taubaté. Apresentação oral. Unpublished manuscript, 2003.

COUDRY, M. I. H. Patologia estabelecida e vivências com o escrito: o que será que dá? Anais do $7^{\circ}$ Encontro Nacional sobre Aquisição da Linguagem, 2006. ENAL. Porto Alegre: CDROM, 2007.

COUDRY, M. I. H. Projeto Integrado em Neurolinguística: avaliação e banco de dados. Relatório de Pesquisa, CNPq: 521773/95-4, de 2007 a 2011. Campinas, SP, 90p. Unpublished manuscript, 2007.

COUDRY, M. I. H. Afasia como tradução. Estudos da Língua(gem), v. 6, n², 7-36, 2008.

COUDRY, M. I. H. Projeto Integrado em Neurolinguística: avaliação e banco de dados. Relatório de pesquisa, CNPq: 301726/2006-0, de 2007 a 2010. Campinas, SP, 65 p. Unpublished manuscript, 2010 .

COUDRY, M. I. H. Dificuldade de viver - Homenagem a Françoise Dolto. Memorial para Concurso de Professor Titular, na área de Neurolinguística, no Departamento de Linguística do Instituto de 
Estudos da Linguagem da Universidade Estadual de Campinas, 92p. Unpublished manuscript, 2012.

COUDRY, M. I. H. Projeto Integrado em Neurolinguística: práticas com a linguagem e documentaç̃o de dados. Relatório de pesquisa, CNPq: 307227/2009-0, de 2010 a 2013. Campinas, SP, 117 p. Unpublished manuscript, 2013.

COUDRY, M. I. H. Patologização de crianças sem patologia. In: VIÉGAS, L. S.; RIBEIRO, M. I. S.; OLIVEIRA, E. C.; TELES, L. A. L.. Medicalização da educação e da sociedade: ciência ou mito?.1 ed.Salvador : EDUFBA, p. 227-247, 2014a.

COUDRY, M. I. H. O que é preciso saber/fazer para enfrentar a patologização?. Mesa Redonda: A Patologização em Pauta: Formação e Intervenção. Apresentação oral. $62^{\circ}$ Seminário do Grupo de Estudos Linguísticos do Estado de São Paulo. Campinas: Unicamp, 2014b.

COUDRY, M. I. H. Neurolinguística discursiva: afasia e infância, um encontro possível. Projeto (Produtividade em Pesquisa CNPq, Processo n. 311504/2016-7). Conselho Nacional de Desenvolvimento Científico e Tecnológico - CNPq, Brasília, 2016.

COUDRY, M. I. H. Neurolinguística Discursiva: afasia e infância - encontro possível/inevitável. Relatório de Pesquisa, CNPq: 312522/2013-4, de 2014 a 2017. Campinas, SP. 78p. Unpublished manuscript, 2016.

COUDRY, M. I. H., BORDIN, S. M. S. Afasia e infância: registro do (in)esquecível. Cadernos de Estudos Linguísticos, Campinas, v. 54, n.1, p. 135-154. Jan./Jun. 2012.

COUDRY, M. I. H.; BORDIN, S. M. S. Ambientes discursivos na afasia e na infância (no prelo).

COUDRY, M. I. H., FREIRE; F. M. P. Avaliação discursiva das afasias. Revista Pesquisa Qualitativa. São Paulo (SP), v.5, n.8, p. 360-377, ago. 2017a.

COUDRY, M. I. H., FREIRE, F. M. P. Fala e leitura: uma (re)entrada para a escrita. In: Cadernos de Estudos Linguísticos - (59.3), Campinas, pp. 565-579 - set./dez. 2017 b.

COUDRY, M. I. H., FREIRE, F. M. P. Investigação qualitativa na avaliação da linguagem de afásicos. Atas $5^{\circ}$ Congresso Ibero-Americano em Investigação Qualitativa (CIAIQ). Porto. v. 3. p. 423432, 2016.

COUDRY, M. I. H., FREIRE, F. M. P. Pressupostos teórico-clínicos da Neurolinguística Discursiva (ND). In: COUDRY, M. I. H., FREIRE, M. I. H., ANDRADE, M. L. F.; SILVA, M. A. (Orgs.). Caminhos da Neurolinguística Discursiva: teorização e práticas com a linguagem. $1^{\text {a }}$ ed. Campinas, SP: Mercado de Letras, p. 23-48, 2010.

COUDRY, M. I. H, FREIRE, F. M. P. O trabalho do cérebro e da linguagem: a vida e a sala de aula. Campinas: Cefiel/IEL/UNICAMP, 2005.

COUDRY, M. I. H., SCARPA, E. M. De como a avaliação de linguagem contribui para inaugurar ou sistematizar o déficit. In: Cadernos Distúrbios da Comunicação, Série Linguagem, 14 (2). São Paulo: PUC, p. 351-360, 1985. 
CULIOLI, A., FUCHS, C., e PÊCHEUX, M. Considérations théoriques à propos du traitement formel du langage. Documents de Linguistique Quantitative, 7. Paris: Dunod, 1970.

FARACO, C. A. Linguagem escrita e alfabetização. 1ª ed. São Paulo: Contexto, 2012.

FEDOSSE, E. Da relação linguagem e praxia: estudo neurolinguístico de um caso de afasia. Dissertação de Mestrado em Linguística. Campinas, IEL-UNICAMP, 2000.

FLOSI, L. C. L. A relação dinâmica da linguagem oral com a escrita e gestos na afasia. Dissertação de Mestrado em Linguística. Campinas, IEL-UNICAMP, 2003.

FORBES, J. Inconsciente e responsabilidade. Psicanálise do século XXI. $1^{\text {a }}$ ed. Barueri, SP: Editora Manole, 2012.

FOUCAULT, M. Vigiar e punir: nascimento da prisão. 1a. ed. 1987. Petrópolis: Vozes, 1987.

FRANCHI, C. Linguagem: atividade constitutiva. Cadernos de Estudos Linguísticos, $\mathrm{n}^{\circ}$ especial, $37-$ 74, 2002. (Data do original: 1977)

FREIRE, F. M. P. Agenda mágica: linguagem e memória. Tese de Doutorado em Linguística. Campinas: IEL-UNICAMP, 2005.

FREIRE, F. M. P. Enunciação e discurso: a linguagem de programação Logo no discurso do afásico. Dissertação de Mestrado em Linguística. Campinas: IEL-UNICAMP, 1999.

FREIRE, F. M. P., COUDRY, M. I. H. Banco de Dados de Neurolinguística: ver, analisar, intervir, teorizar. Atas do $5^{\circ}$ Congresso Ibero-Americano em Investigação Qualitativa (CIAIQ), Porto. v. 3. p. 367-376, 2016.

FREIRE, F. M. P., KOBAYASHI, A., GARCIA, B. L., COUDRY, M. I. H. Entre lápis e teclas: selecionando e combinando letras. Cadernos de Estudos Linguísticos, v. 55, p. 45-65, 2013.

FREUD, S. Pour concevoir les aphasies. Une étude critique. 1 ire. Edition. Traduction de Fernand Cambon. Paris: EPEL, 2010. (Data do original: 1891).

GREGOLIN-GUINDASTE, R. M. O agramatismo: um estudo de caso em português. Tese de Doutorado em Linguística. Campinas: IEL, UNICAMP, 1996.

HADLER, M. I. Considerações iniciais sobre sistemas neurais e linguagem. Dissertação de Mestrado em Linguística. Campinas: IEL-UNICAMP, 1978.

HELLER-ROAZEN, D. Ecolalias: sobre o esquecimento das línguas. Trad. Fabio A. Durão. Campinas (SP): Editora UNICAMP, 2010. (Data do original: 2005).

JACKSON, H. On the nature of the duality of the brain. Medical Press and Circular 1: 19, 41 and 63. Reprinted in Brain 38:80-86; 87-95; 96-103, 1915. (Data do original: 1874). 
JAKOBSON, R. Langage enfantin et aphasie. $1^{\text {ire }}$. Edition. Paris: Flammarion, 1980. (Data do original : 1941).

LABIGALINI, A. P. V. Reflexões sobre a práxis fonoaudiológica à luz da Neurolinguística Discursiva. Dissertação de Mestrado em Linguística. Campinas-SP: IEL-UNICAMP, 2009.

LEMOS, C. T. G. de. A. Sobre aquisição de linguagem e seu dilema (pecado) original. Boletim da ABRALIN, Curitiba, n.3, p.97-126, 1982.

LURIA, A. R. Fundamentos de Neuropsicologia. $1^{\text {a }}$ ed. São Paulo: EDUSP, 1981.

LURIA, A. R. Neuropsichological studies in afasia. Amsterdam: Swets \& Zeitlinger, 1977.

MAINGUENEAU, D. Approche à l'énonciation en Linguistique Française. Paris: Hachette, 1981.

MAINGUENEAU, D. Análise de textos de comunicação. Trad. Souza-e-Silva, C. P. de; Rocha, D. São Paulo: Cortez, 2004. (Data do original: 1998).

MAINGUENEAU, D. Ethos, cenografia, incorporação. In: AMOSSY, Ruth (Org.). Imagens de si no discurso: a construção do ethos. Trad. Dilson Ferreira da Cruz, Fabiana Komesu e Sírio Possenti. São Paulo: Contexto, p.69-92, 2005.

MAINGUENEAU, D. Novas tendências em Análise do discurso. $1^{\text {a }}$ ed. Campinas, SP: Pontes, 1989. (Data do original: 1987).

MASSINI-CAGLIARI, G., CAGLIARI, L. C. Diante das letras: a escrita na alfabetização. São Paulo: Ed. FAPESP, 2001.

MIGLIORINI, L.; MASSINI-CAGLIARI, G. Sobre o ritmo do português brasileiro: evidências de um padrão acentual. ReVEL, v.8, n15, 2010. Disponível e: www.revel.inf.br.

MORATO, E. M. et alii. Sobre as afasias e os afásicos: subsídios teóricos e práticos elaborados pelo Centro de Convivência de Afásicos (CCA). Campinas: Ed. Unicamp, 2002.

MOUTINHO, I. Transtorno Específico de Aprendizagem: uma análise Neurolinguística. Dissertação de Mestrado em Linguística. Campinas: IEL, UNICAMP, 2014.

MULLER, L. M. M. Sujeitos, histórias e rótulos: a leitura e a escrita de crianças e jovens diagnosticados de Dislexia. Dissertação de Mestrado em Linguística. Campinas: IEL-UNICAMP, 2013.

NOVAES-PINTO, R. Agramatismo: uma contribuição para o estudo do processamento normal da linguagem. Dissertação de Mestrado em Linguística. Campinas: IEL, UNICAMP, 1992.

NOVAES-PINTO, R. A contribuição do estudo discursivo para uma análise crítica das categorias clínicas. Tese de Doutorado em Linguística. Campinas: IEL-UNICAMP, 1999.

OSAKABE, H. Argumentação e discurso político. São Paulo: Kairós, 1979. 
POSSENTI, S. Aprender a escrever (re)escrevendo. São Paulo: Cefiel/IEL/UNICAMP e MEC, 2005.

RIBEIRO, I. Quais as faces do português culto brasileiro. In: ALKMIM, T. (Org.). Para a História do Português Brasileiro. vol.III São Paulo, SP: Humanitas, p. 359-382, 2001.

RIGHI-GOMES, M. J. A escola atual à luz da neurologia e da neurolinguística. Tese de Doutorado em Linguística. Campinas: IEL-UNICAMP, 2014.

SAUSSURE, F. Cours de Linguistique Générale. Org. por Ch. Bally et Sechehaye, avec la colaboration de Riedlinger. Paris: Payot, 1969. (Data do original: 1916).

SANTANA, A. P. Escrita e afasia: a linguagem escrita na afasiologia. São Paulo: Plexus, 2002.

SILVA, M. A. Estudo neurolinguístico de duas crianças portadoras da Síndrome do X-Frágil. Tese de Doutorado em Linguística. Campinas: IEL-UNICAMP, 2014.

VIGOTSKY, L. S. Psicologia Pedagógica. São Paulo: Martins Fontes, 2004. (Data do original: 1926).

VYGOTSKY, L. S. Pensamiento Y Habla. $1^{\text {a }}$ ed. Buenos Aires: Colihue, 2007. (Data do original: 1934). 